\title{
EVALUASI PENGGUNAAN ANTIBIOTIK PADA PASIEN GONORE DI RSUD AWS SAMARINDA BERDASARKAN ATC/DDD DAN DU90\%
}

\author{
Fatmawati Eka Putri, Febrina Mahmudah, Hadi Kuncoro \\ Laboratorium Penelitian dan Pengembangan Kefarmasian "Farmaka Tropis", \\ Fakultas Farmasi, Universitas Mulawarman, Samarinda, Indonesia \\ *Email: fatmaekaputri64@gmail.com
}

\begin{abstract}
Gonorrhea is a sexually transmitted disease caused by Neisseria gonorrhoeae bacteria which can be treated with antibiotics. This study aims to determine the description and quantity of antibiotic use in gonorrhea. This study was a descriptive study with a retrospective study taken from medical records to assess the quantity and quality of antibiotic use. Samples were taken by means of total sampling. The results showed that out of 66 medical records, total antibiotic use was 54.33DDD/1000 KPRJ and antibiotics were entered in DU90\% namely cefixime (28.8DDD/1000 KPRJ), azithromycin (14.1DDD/1000 KPRJ), amoxicillin (3.2DDD/1000 KPRJ), doxycycline (3.2DDD/1000 KPRJ), levofloxacine (2.12DDD/1000 KPRJ), ciprofloxacin (1.7DDD/1000 KPRJ) and gentamicin $(0.7 \mathrm{DDD} / 1000 \mathrm{KPRJ})$. The conclusion of the research showed that the quantity of antibiotics used was the most cefixime in the amount of 28.8DDD / 1000 KPRJ.
\end{abstract}

Keywords: Gonorrhea, Neisseria gonorrhoeae, ATC / DDD and DU 90\%.

\begin{abstract}
ABSTRAK
Gonore merupakan penyakit menular seksual yang disebakan oleh bakteri Neisseria gonorrhoeae yang dapat diobati dengan antibiotik. Penelitian ini bertujuan untuk mengetahui gambaran dan kuantitas penggunaan antibiotik pada penyakit gonore. Penelitian ini merupakan penelitian deskriptif dengan studi retrospektif yang diambil dari catatan medik untuk menilai kuantitas dan kualitas penggunaan antibiotik. Sampel diambil dengan cara total sampling. Hasil penelitian menunjukkan bahwa dari 66 catatan medik didapatkan total penggunaan antibiotik 54,33 DDD/1000 KPRJ dan antibiotik yang masuk dalam DU 90\% yaitu cefixime (28,8 DDD/1000 KPRJ), azitromisin (14,1 DDD/1000 KPRJ), amoxicillin (3,2 DDD/1000 KPRJ), doxycycline (3,2 DDD/1000 KPRJ), levofloxacine (2,12DDD/1000 KPRJ), ciprofloxacin (1,7 DDD/1000 KPRJ), dan gentamisin (0,7DDD/1000 KPRJ). Kesimpulan penelitian yang didapat menunjukkan bahwa secara kuantitas penggunaan antibiotik yang paling banyak adalah cefixime sebesar 28,8DDD/1000 KPRJ.
\end{abstract}

Kata Kunci: Gonore, Neisseria gonorhoeae, ATC/DDD dan DU90\%

DOI: https://doi.org/10.25026/mpc.v7i1.284 


\section{PENDAHULUAN}

Antibiotik merupakan golongan obat dengan jumlah pemakain yang paling sering digunakan dalam penggunaan, terutama terkait dengan kejadian infeksi bakteri. Bersamaan dengan peningkatan penggunaan antibiotik, berbagai permasalahan dapat terjadi seperti pemakaian antibiotik yang tidak rasional, peningkatan resistensi antibiotik dan peningkatan harga antibiotik. Gonore merupakan penyakit menular yang disebabkan oleh bakteri Neisseria gonorrhoeae yang termasuk bakteri diplococcus gram negatif dan manusia merupakan satu-satunya faktor alamiah untuk gonokokus, infeksi gonore hampir selalu ditularkan saat aktivitas seksual. Penyakit menular ini paling sering dilaporkan dan masih menjadi masalah di negara berkembang ataupun negara maju dan juga penyakit dengan prevalensi yang tinggi setiap tahun sekitar 78 juta penderita. Angka kejadian gonore berkaitan dengan resistensi terhadap antibiotik yang digunakan dalam pengobatan gonore. Resistensi dapat dipengaruhi dengan perilaku cara pengobatan, yaitu berobat ke dokter dan berobat sendiri (Rizal, 2011).

Penggunaan antibiotik perlu dievaluasi, diketahui penggunaan antibiotik yang berlebihan dapat meningkatkan terjadinya resistensi. Diperlukan suatu studi penggunaan antibiotik untuk meningkatkan rasionalitas penggunaan antibiotik. World Health Organization (WHO) telah menetapkan ATC/DDD dan DU90\% yang merupakan metode terstandar untuk studi penggunaan obat. Metode ATC/DDD yaitu metode kuantitatif yang digunakan dalam penelitian penggunaan obat untuk meningkatkan kualitas penggunaan obat. Dengan menggunakan metode ATC/DDD, hasil evaluasi penggunaan obat dapat dengan mudah dibandingkan (WHO, 2011).

Metode Drug Utilization $90 \%$ (DU90\%) merupakan metode yang menggambarkan pola penggunaan obat. DU90\% merupakan daftar obat yang masuk dalam akumulasi $90 \%$ penggunaan setelah diurutkan dari persentase penggunaan terbesar hingga terkecil. DU90\% bertujuan membuat pengelompokkan data statistik penggunaan obat sehingga kualitas penggunaan obat dapat dinilai. Drug Utilization $90 \%$ (DU90\%) adalah pengembangan lebih lanjut dari data yang diberikan baik data kuantitatif maupun data kualitatif ( Sofa, 2012).

\section{METODE}

Penelitian ini dilaksanakan di Instalasi Rekam Medik Rumah Sakit Awahab Sjahranie Samarinda mulai bulan Agustus sampai Oktober 2018. Jenis penelitian deskriptif analitik (total sampling) dengan pengambilan data secara retrospektif. Data yang diperoleh adalah jenis antibiotik, dosis antibiotik, cara pemberian antibiotik, kekuatan antibiotik, serta jumlah kunjungan pasien rawat jalan.

Data kuantitas penggunaan antibiotik dengan kode ATC J01 yang menunjukan kode antiinfeksi untuk penggunaan sistemik diambil dan diolah dengan menggunakan metode ATC/DDD dengan satuan unit DDD/1000KPRJ/tahun. Metode ini yang digunakan untuk menganalisis kuantitas dan kualitas penggunaan obat

Segmen penggunaan antibiotik terbanyak ditetapkan berdasarkan metode DU 90\%, dengan mengurutkan persentase penggunaan pada periode penelitian dari yang terbesar hingga yang terkecil yang kemudian diambil segmen $90 \%$ penggunaan terbanyak. 
HASIL

Evaluasi kuantitatif penggunaan antibiotik dianalisis menggunakan sistem ATC/DDD yang ditetapkan oleh World Health Organization (WHO). Hasil analisis menunjukkan bahwa penggunaan antibiotik dalam satuan DDD/1000. Dari 66 catatan rekam medik pada bulan Agustus sampai Oktober 2018 yang masuk bagian penyakit Gonore di Rumah Sakit Awahab Sjahranie Samarinda (AWS) yang diambil, terdapat 130 peresepan antibiotik tersebut, dengan variasi tiap pasien mendapatkan satu sampai dua antibiotik. Didapatkan kuantitas Cefixime yang paling tinggi, menunjukan penggunaan antibiotik Cefixime paling banyak dibanding dengan obat antibiotik yang lain. Pola konsumsi antibiotik pada periode penelitian ini dapat dilihat pada tabel 1 .

Berdasarkan pola konsumsi antibiotik yang ditampilkan pada Tabel 2, dapat diketahui antibiotik apa saja yang masuk ke dalam segmen DU 90\% penggunaan. Hasil penelitian menunjukkan bahwa jenis antibiotik Cefixime yang merupakan antibiotik paling banyak digunakan yaitu senilai 28,8 DDD/1000KPRJ. Penggunaan golongan yang masuk dalam segmen DU90\% yaitu cefixime azitromisin, amoxicillin,doxycycline, levofloxacin, ciprofloxacin, gentamisin. Penggunaan antibiotik tersebut perlu diikuti dengan evaluasi dalam penggunaan rasional untuk menghindari resistensi antibiotik segmen DU90\% terbanyak yaitu pada cefixime golongan sefalosporin.

Tabel 1. Kuantitas Penggunaan Antibotik dengan DDD/1000KPRJ

\begin{tabular}{lccc}
\multicolumn{1}{c}{ Jenis Antibiotik } & $\boldsymbol{\Sigma}$ Dosis (g) & DDD & DDD/1000 \\
\hline Cefixime & 84 & 81,5 & 28,8 \\
Amoxicillin & 9 & 9 & 3,2 \\
Doxycycline & 9 & 9 & 3,2 \\
Levofloxacin & 3 & 6 & 2,1 \\
Azitromisin & 12 & 40 & 14,1 \\
Ciprofloxacin & 5 & 5 & 1,7 \\
Cefadroxil & 3 & 1,5 & 0,5 \\
Gentamisin & 0,5 & 2 & 0,7 \\
Ceftriaxone & 0,25 & 0,1 & 0,03 \\
Total & & $\mathbf{1 5 3 , 2}$ & $\mathbf{5 4 , 3 3}$ \\
\hline
\end{tabular}

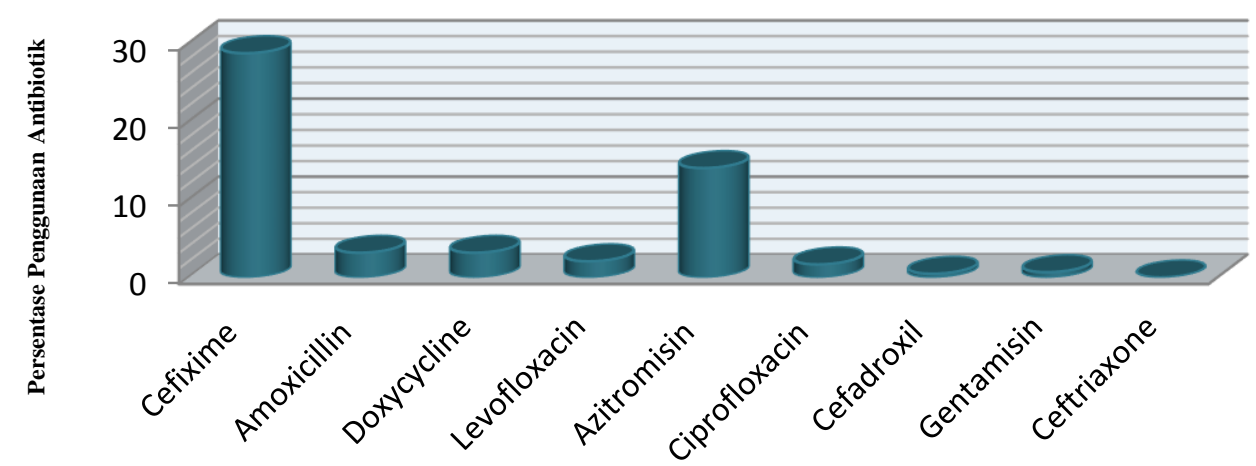

Antibiotik

Gambar 1 Kuantitas Penggunaan Antibiotik Berdasarkan DDD/1000KPRJ 
Tabel 2. Pola Konsumsi Jenis Antibioik Pasien Gonore

\begin{tabular}{lccc}
\hline \multicolumn{1}{c}{ Jenis Antibiotik } & DDD & \%DDD & Segmen DU \\
\hline Cefixime & 81,5 & 53 & \\
Azitromisin & 40 & 26 & $90 \%$ \\
Amoxicillin & 9 & 5,8 & \\
Doxycycline & 9 & 5,8 & \\
Levofloxacin & 6 & 4 & \\
Ciprofloxacin & 5 & 3,2 & $10 \%$ \\
Gentamisin & 2 & 1,3 & \\
Cefadroxil & 1,5 & 0,9 & \\
Ceftriaxone & 0,1 & 0,06 & \\
Total & $\mathbf{1 5 3 , 2}$ & $\mathbf{1 0 0 , 0 6}$ & \\
\hline
\end{tabular}

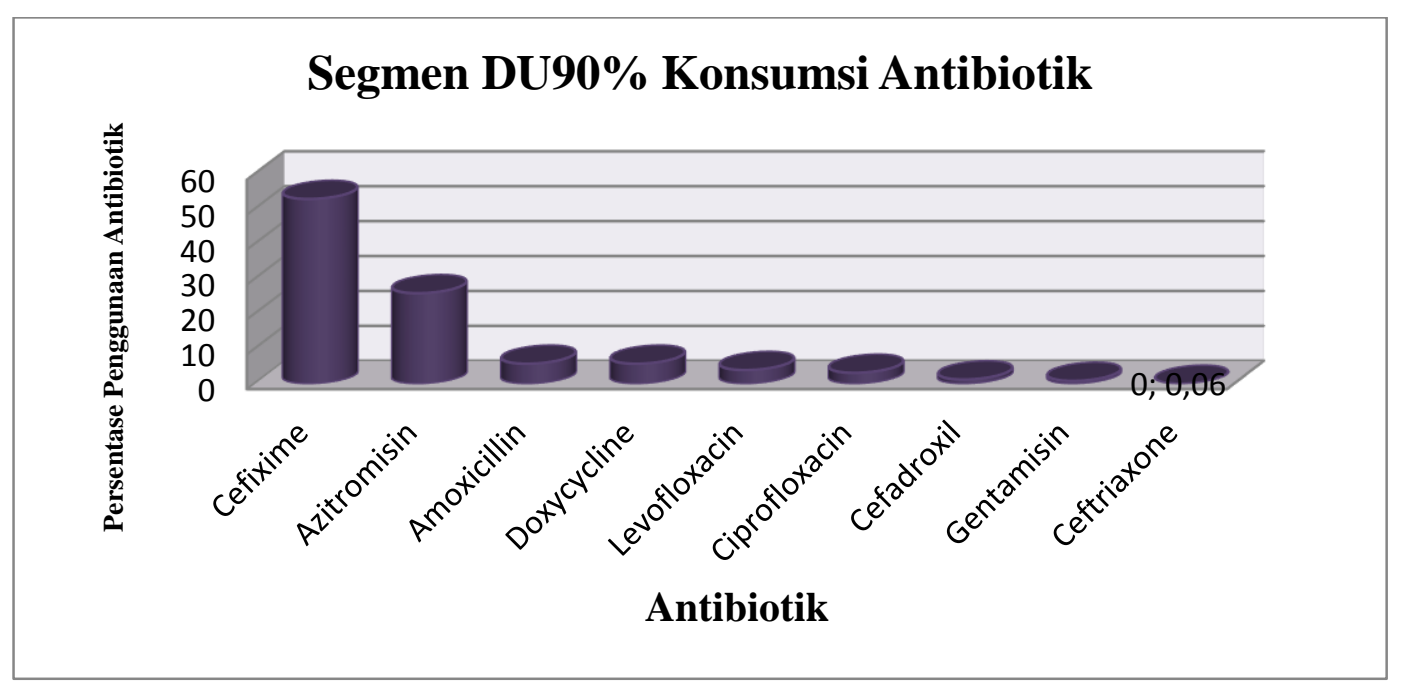

Gambar 2 Pola Konsumsi Antibiotik yang Masuk ke dalam Segmen DU90\%

\section{PEMBAHASAN}

Penelitian ini dilakukan di Rumah Sakit Awahab Sjahranie Samarinda. Kasus Gonore di Rumah Sakit AWS ini laki-laki lebih banyak beresiko terinfeksi Neisseria gonorrhoeae yaitu sekitar $24,07 \%$. Hal ini dikarenakan karena lakilaki yang terinfeksi selalu menunjukan gejala atau bersifat simptomatis sehingga akan segera memeriksakan diri untuk memperoleh pengobatan. Sementara wanita yang terinfeksi tidak mengeluhkan adanya gejala atau bersifat asimptomatis, oleh sebab itu tidak segera mencari pengobatan. Setiap tahun diperkirakan terdapat 78 juta penderita yang tertular penyakit Gonore.

Peningkatan

penggunaan antibiotik, dapat menimbulkan berbagai permasalahan yang dapat terjadi seperti pemakaian antibiotik yang tidak rasional, peningkatan resistensi antibiotik dan peningkatan harga antibiotik. Perilaku pemakaian antibiotik pada penderita gonore berkaitan dengan tingkat pemahaman dan pengetahuan tentang penyakit yang dideritanya dan pengetahuan tentang antibiotik itu sendiri. Serta penggunaan terakhir antibiotik, intensitas pemakaian 
antibiotik, pengetahuan tentang aluran pakai, tindakan mengganti antibiotik, efek samping serta pengetahuan tentang resistensi antibiotik, sering digunakan sebagai acuan untuk menilai perilaku pemakaian antibiotik.

Dinas kesehatan menerapkan suatu kebijakan untuk mengendalikan penggunaan antibiotik, salah satunya adalah pada penyakit menular Gonore. Kebijakan ini tentunya sangat baik untuk mencegah penggunaan obat antibiotik yang tidak terkendali yang akhirnya akan berdampak pada terjadinya resistensi.

Dalam penelitian ini di dapatkan 9 variasi pengggunaan antibiotik yang termasuk dalam pengobatan penyakit Gonore dengan total 54,33DDD/1000KPRJ. Golongan obat yang paling banyak diberikan adalah golongan sefalosporin generasi ketiga yaitu Cefixime sebesar 28,8 DDD/1000KPRJ kemudian diikuti dengan Azitromisin sebesar 14,1 DDD/1000KPRJ. Hal ini karena obat cefixime merupakan antibiotik pilihan pertama yang dapat digunakan untuk mengeradikasi bakteri Neisseria gonorrhoeae. Hal ini sesuai dengan Kemenkes RI (2011) bahwa penatalaksana utama bakteri Neisseria gonorrhoeae juga dengan pemberian cefixime. Sefalosporin memiliki sifat yang lebih stabil terhadap cincin $\beta$-laktam yang diproduksi bakteri sehingga memiliki spektrum kerja yang lebih luas. Mekanisme kerja sefalosporin dalam menghambat sintesis dinding sel bkteri yaitu dengan cara menghambat protein pengikat penisilin. Terapi dosis tunggal yang dianjurkan untuk gonore yang tanpa komplikasi yaitu $400 \mathrm{mg}$ peroral.

Semua dosis antibiotik yang digunakan untuk penyakit Gonore, termasuk dalam underuse karena kurang dari ketetapan dosis dari WHO. Seperti, cefixime yang didapat 0,02 gram, sedangkan berdasarkan WHO cefixime sebesar 0,4 gram, antibiotik amoxicillin 0,003 gram sedangkan standar WHO untuk amoxicillin sebesar 1 gram, antibiotik doxycycline 0,003 gram, berdasarkan standar WHO doxycycline sebesar 0.1 gram, obat antibiotik levofloxacin 0,002 gram, berdasarkan standar dari WHO levofloxacin sebesar 05 gram. Obat azitromisin 0,014 gram, berdasarkan WHO azitromisin sebesar 0,3 gram. Untuk obat ciprofloxacin 0,017 gram, sedangkan berdasarkan standar WHO ciprofloxacin sebesar 1 gram, obat cefadroxil yang didapat 0,001 gram, sedangkan standar WHO cefadroxil sebesar 2 gram, obat gentamisin sebesar 0,0007 gram untuk standar WHO gentamisin sebesar 0,24 gram dan antibiotik ceftriaxone yang didapat sebesar 0,00003 gram sedangkan berdasarkan WHO ceftriaxone sebesar 2 gram.

Terdapat 9 jenis antibiotik yang dikonsumsi pada pasien Gonore pada periode Agustus - Oktober tahun 2018 dengan 7 jenis antibiotik yang masuk ke dalam segmen DU90\% penggunaan terbanyak yaitu cefixime, azitromisin, amoxicillin, doxycycline, levofloxacin, ciprofloxacin dan gentamisin, yang dapat dilihat pada gambar 2. Banyaknya variasi jenis antibiotik menyebabkan rentannya insiden resistensi antibiotik dan meningkatkan peluang resistensi terhadap antibiotik yang digunakan.

Metode ATC/DDD dan DU90\% ini dapat digunakan untuk mengetahui kemungkinan ketidak rasionalan penggunaan obat melalui identifikasi underuse atau overuse. Selain itu metode ini dapat mengevaluasi untuk meminimalisir efek negatif penggunaan antibiotik meliputi resistensi antibiotik, adverse drug reaction, dan peningkatan beban biaya obat pasien.

\section{KESIMPULAN}

Hasil penelitiaan menunjukan secara kuantitatif penggunaan antibiotik yang paling banyak digunakan untuk pasien gonore di Rumah Sakit Awahab Sjahranie Samarinda adalah antibiotik 
cefixime sebesar 28,8 DDD/1000KPRJ dan yang paling sedikit antibiotik ceftriaxone yaitu sebesar $0,03 \mathrm{DDD} / 1000$ KPRJ. Terdapat 9 jenis antiobotik yang digunakan tetapi hanya 7 jenis antibiotik yang masuk ke DU90\% yaitu cefixime, azitromisin, amoxicillin, doxycycline, levofloxacin ciprofloxacin dan gentamisin.

\section{DAFTAR PUSTAKA}

[1] Sofa D, Alfian, Eva, S. 2012. Profil Penggunaan Antituberkolosis Di Kota Bandung Periode 2000-2010. Jurnal Farmasi Klinik Indonesia Volume 1, nomor 4 : Sumedang.

[2] World Health Organization. 2011. The World Medicine Situation 2011 3ed. Rational Use of Medicine : Geneva.

[3] Afriana, N. 2012. Faktor-Faktor Yang Berhubungan Dengan Kejadian Infeksi Gonore pada Wanita (Analisis Data Sekunder Survei Terpadu Biologi dan Perilaku 2011, Tesis. Program Studi Epidemiologi Komunitas Universitas Indonesia : Depok.
[4] Rahayu Pudji, R. 2016. Kajian Karakteristik dan Pola Pengobatan Pasien Infeksi Menular Seksual Di RSUD AW Sjahranie Samarinda. Jurnal Prosiding Seminar Nasional Kefarmasian Ke-4 : Samarinda.

[5] Pani Sari, dkk. 2015. Monitoring Penggunaan Antibiotik dengan Metode ATC/DDD dan DU 90\%: Studi Observasional di Seluruh Puskesmas Kabupaten Gorontalo Utara. Jurnal Farmasi Klinik Indonesia Vol. 4 No. 4, hlm 275280. ISSN: 2252-6218.

[6] Mahmudah Febrina, dkk. 2016. Studi Penggunaan Antibiotik Berdasarkan ATC/DDD dan DU90\% di Bagian Bedah Digestif di Salah Satu Rumah Sakit di Bandung. Jurnal Farmasi Klinik Indonesia Vol. 5. No. $4 \mathrm{Hal}$ : 293-298. ISSN: 2252-6218

[7] Yuniarti Pudji Rahayu, Adam M. Ramadhan, Laode Rijai. 2016. Kajian Karakteristik Dan Pola Pengobatan Pasien Infeksi Menular Seksual Di Rsud Aw Sjahranie Samarinda. Prosiding Seminar Nasional Kefarmasian Ke 4 : Samarinda. 